\title{
Fibular Non-Vascularized Graft Might be a Practical Solution for Treatment of Osteopenic Humeral Shaft Non-union in Elderly Obese Patients
}

\author{
Yaşlı Obez Hastalardaki Kaynamayan Osteopenik Humerus Şaft Kırıklarında Nonvaskülarize Fibula \\ Grefti Pratik Bir Çözüm Olabilir
}

\author{
Ayhan Kılıç, Armağan Arslan, Harun Mutlu, Engin Çetinkaya, Cüneyt May, Atilla Sancar Parmaksızoğlu \\ Clinic of Orthopedics, Taksim Training and Research Hospital, İstanbul, Turkey
}

\begin{abstract}
Objective: The study aim was to report on the use of intramedullary fibular strut autograft and plate fixation in diaphyseal atrophic non-union of the humerus in elderly obese patients.

Methods: Between 2001 and 2006, 4 patients with diaphyseal non-union of the humerus were treated in our institution by intramedullary fibular autograft and AO plate fixation. Average age of the patients was 67 years (range, 65-69) and BMI (Body Mass $1 \mathrm{ndex}): 39 \mathrm{~kg} / \mathrm{m}^{2}(\mathrm{range}, 35-42.5)$. There were three females and one male. The patients each had fractures of mid-shaft and junction of middle and proximal thirds. Three were closed fractures and one open fracture had eventual atrophic non-union upon presentation. Data collected retrospectively included grip strength, range of motion, radiographic parameters, and functional outcomes as measured by the DASH (Disabilities of the Arm, Shoulder and Hand) questionnaire.

Results: Patients were followed-up for an average of 4 years (range, 3-6). Union was achieved in all patients in 3. 2 months (range, 3-4) and patients were very satisfied with the treatment. There were no perioperative complications. The average humeral shortening was $2.7 \mathrm{~cm}(\mathrm{range}, 1-5)$. Preoperative DASH score averaged 58 points (range, 47. 7-70. 5). DASH score at the last follow-up averaged 17 points (range, 9-20. 4).

Conclusion: The surgical treatment of humerus diaphyseal non-unions in elderly and obese patients is not only difficult but also costly. Moreover,time consuming surgical interventions brings life-threatening risks in particular in those patient populations. Thus, we consider this method to be an applicable treatment alternative where humerus diaphyseal union is obtained. (JAREM 2011; 1: 15-7)
\end{abstract}

Key Words: Humerus diaphyseal, non-union, quadricortical bone grafting, fibular autograft, obesity, elderly patient

\section{ÖZET}

Amaç: Yaşlı, obez hastalardaki kaynama sorunlu humerus diafiz kırıklarında damarsız fibula otogrefti ve plak vida tespitiyle elde edilen tedavi sonuçlarını bildirmeyi amaçladık.

Yöntemler: 2001-2006 yılları arasında kliniğimizde kaynama sorunları olan humerus diafiz kırıkları nedeniyle tedavi edilen 4 hasta (3 kadın, 1 erkek) bu çalışmada değerlendirildi. Hastaların ortalama yaşı 67 (65-69 yıl), VKi (vücut kitle indeksi): 39 kg/m² (35-42.5) idi. Tüm hastalarda orta ve 1/3 proksimal humerus bölgesinde şaft ortası kırığı saptandı. 3 hastada kapalı kırık, 1 hastada atrofik non-union gelişimine neden olmuş açık kırık öyküsü mevcuttu. Retrospektif olarak değerlendirilen hastaların kavrama gücü, eklem hareket açıklı̆ı ölçüldü ve radyografik olarak kırık iyileşmesi değerlendirildi. DASH üst ekstremite işlevleri anketleri yapıldı.

Bulgular: Ortalama 4 yıl (3-6 yıl) süreyle takip edilen hastalarda 3.2 ay (3-4 ay) içinde kaynama geliştiği görüldü. Hiçbir hastada perioperatif komplikasyon gelişmedi. Ortalama humeral kısalma $2.7 \mathrm{~cm}(1-5 \mathrm{~cm})$ olarak saptandı. Hastaların preoperatif dönemdeki DASH skorları ortalama 58 puan (47.770.5) iken son kontrollerde ortalama 17 puana (9-20.4) geriledi.

Sonuç: Yaşlı ve obez hastalarda görülen humerus diafizi kaynama sorunlu kırıkların cerrahi tedavisi zor olmasının yanısıra pahalıdır. Ayrıca bu hasta grubunda uygulanacak karmaşık cerrahi girişimler hastanın hayati risklerini daha da artırabilir. Bu sebeplerden dolayı uyguladığımız yöntemin iyi bir alternatif olacağını düşünüyoruz. (JAREM 2011; 1: 15-7)

Anahtar Sözcükler: Humerus diafiz, non-union, dört korteks destekli greftleme, fibula otograft, obezite, yaşlı hasta

\section{INTRODUCTION}

Non-union of the humeral shaft is not a rare condition and is a complication of both nonoperative and operative treatment of the fracture (1-3). Systemic factors include age malnutrition, smoking, diabetes, morbid obesity, osteoporosis, immunocompromised conditions and coagulopathy. Local factors include soft-tissue and bone loss, soft-tissue fibrosis, infection, malalignment, joint contracture and degenerative joint disease (4). Only a few of these factors may directly inhibit bone formation. However, all such factors influence the decision-making of the surgeon, in determining the optimal treatment of a non-union in an individual patient. In oligo-atrophic non-unions, reestablishment of stability has a higher priority than facilitating the circulation (5). Various surgical procedures have been described to treat symptomatic non-union, including intramedullary nails, external fixation and plating, in conjunction with vascularized and nonvascularized bone grafts, with prevention having been reported to be the best treatment for this condition (6-20). However, the use of vascularized grafts that require advanced skills and special set-ups is controversial due to the high costs, time consuming surgery as well as the low profile contribution to stability at the fracture site $(15,16)$. In addition, these operative techniques for normal body-size patients are often difficult to adapt to the 
obese patient. Surgery in the morbidly obese has been associated with respiratory problems, anaesthetic difficulties and wound complications (17).

In conjunction with the matter, relatively easy, less costly methods that take less time are needed to ensure stability at an acceptable level, in elderly, obese and osteoporotic patients. This retrospective study aim was to evaluate the longterm outcome of the treatment of osteopenic humeral shaft non-unions with quadricortical non-vascularized fibular autografts in debilitated patients.

\section{METHODS}

Between 2001 and 2006, 4 patients with diaphyseal non-union of the humerus were treated in our institution by intramedullary fibular autograft and $\mathrm{AO}$ plate fixation. Average age of the patients was 67 years (range, 65-69) and BMI (Body Mass Index): $39 \mathrm{~kg} / \mathrm{m}^{2}$ (range, 35-42.5). There were three females and one male. The patients each had fractures of mid-shaft and junction of middle and proximal thirds. Three were closed fractures and one open fracture had eventual atrophic non-union upon presentation. The patients had mild pain, tenderness and abnormal mobility at the non-union site, and limitation of activities of daily living. All patients had stiffness of shoulder and elbow to varying degrees. None of the patients were smokers.

Inclusion criteria; (1) Other lines of treatment had failed or were unsuitable. (2) Non-union $>6$ months. (3) Associated with severe osteoporosis (4) Age $>65 \mathrm{yrs}$. (5) BMI $>30 \mathrm{~kg} / \mathrm{m}^{2}$. Osteoporosis was defined radiologically as marked thinning out of the cortical bone and widening of the medulla. Three out of 4 patients had had failed plate fixation and Ilizarov fixator. One patient presented after failed prolonged conservative treatment in a functional brace. Average delay at presentation from the time of injury was 18 months (range, 10-22).

\section{Surgical Technique}

All patients underwent surgery under general anaesthesia. The patient was positioned in a semi-sitting position with the involved arm free draped (Figure 1). Preoperative antibiotics were administered in the form of cefazolin $2 \mathrm{~g}$ intravenously and continued for $24 \mathrm{~h}$ postoperatively.

1. Surgical exposure: The humerus was exposed through a lateral approach in all patients with exploration and neurolysis of the radial nerve out of the non-union site.

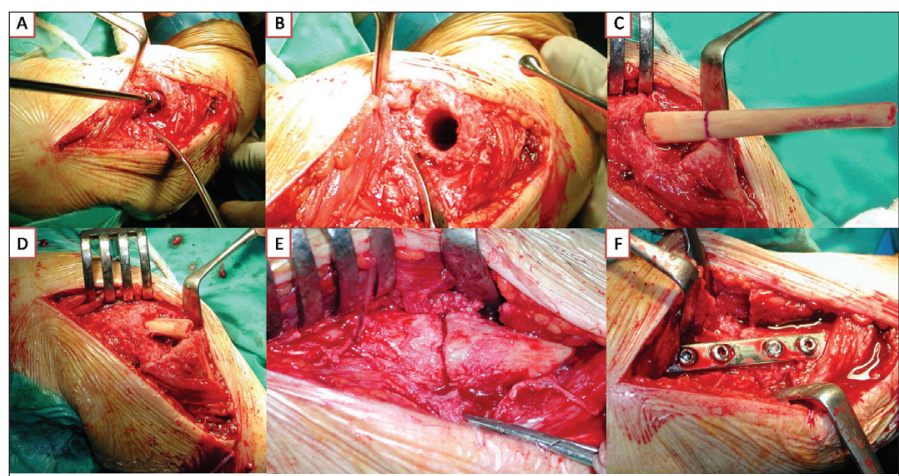

Figure 1. The medullary canal was opened usually using a hand reamer of 7-mm diameter, followed gradually and cautiously by the larger reamers up to the size that could fit to the diameter of the medullary canal. The largest reamer size used was $12 \mathrm{~mm}(\mathrm{~A}, \mathrm{~B})$. The strut autograft was pushed into one of the fracture fragments and the exact length of graft that needed trimming was assessed $(C, D)$ The fracture was reduced with the intramedullary fibular graft spanning the fracture site. Osteosynthesis across the fracture site was achieved $(E, F)$
2. Excision of the pseudoarthrosis: The fibrous non-union and any devitalised bone were thoroughly excised and the medullary canal was opened.

3. Preparation of the medullary canal: The humeral medullary canal was prepared to accept the bone graft. Fibrous and pseudoarthrosis tissue were removed completely and the medullary cavity reconstituted both proximally and distally by curettage, drill or the use of serial hand reamers $(7 \mathrm{~mm}-12 \mathrm{~mm})$.

4. Raising the fibular graft: The mid-shaft of the fibula was then harvested under tourniquet control with care taken to identify and protect the superficial peroneal nerve. The fibular shaft of excess length was harvested so that it could be trimmed as necessary. The fibula graft was trimmed so as to enable it to telescope snugly into the fragments across the fracture site.

5. Insertion of the fibular graft: The strut was pushed into one of the fracture fragments and the exact length of graft that needed trimming was assessed. Once the final shaping of the graft was done, the fracture was reduced with the intramedullary fibular graft spanning the fracture site.

6. Plate fixation: A narrow DCP was used with quadricortical screw fixation. Each screw hole was drilled and tapped through four cortices, two in the fractured bone and two in the intact fibula and $4.5 \mathrm{~mm}$ cortical screws were inserted. There was only tri-cortical screw fixation on the two occasions, where half of a split fibula was used to fit a narrow canal. The surgical wound was closed in layers over negative suction drain.

Shoulder and elbow exercises were started a day after the operation. Lifting of weights using the operated limb was deferred for a period of three months or until osseointegration of the fibular ends or fracture healing. After hospital discharge, patients were observed on a monthly basis until healing of the fracture. All patients were examined both clinically and radiologically. Fracture union was considered radiographically if callus formation was seen in three of four cortices on anteroposterior and lateral views. Clinical union was considered when the fracture site was painless.

Data collected retrospectively included grip strength, range of motion, radiographic parameters, and functional outcomes as measured by the DASH (Disabilities of the Arm, Shoulder and Hand) questionnaire.

\section{RESULTS}

Patients were followed-up for an average of 4 years (range, 3-6). Union was achieved in all patients in 3.2 months (range, 3-4) and patients were very satisfied with the treatment (Figure 2). There were no perioperative complications such as wound infection, radial nerve palsy, hematoma formation and discomfort over the fibular graft harvest site. The average humeral shortening was 2 . $7 \mathrm{~cm}$ (range, 1-5). Preoperative DASH score averaged 58 points (range, 47. 7-70. 5). DASH score at the last follow-up averaged 17 points (range, 9-20.4). There was an average loss of $40^{\circ}$ abduction and $30^{\circ}$ flexion of the shoulder. There was no change in shoulder rotations following surgery. All patients with preoperative fixed flexion deformity of elbow to varying degrees had persistence of a similar deformity at the last follow-up.

\section{DISCUSSION}

The early identification and treatment of non-union is paramount in preserving the soft tissues and functional outcome. In case of non-union, mechanical stability at the fracture site and biologic revitalization are keys for the management $(5,18)$. Numerous surgical methods have been described for the treatment of humeral shaft 

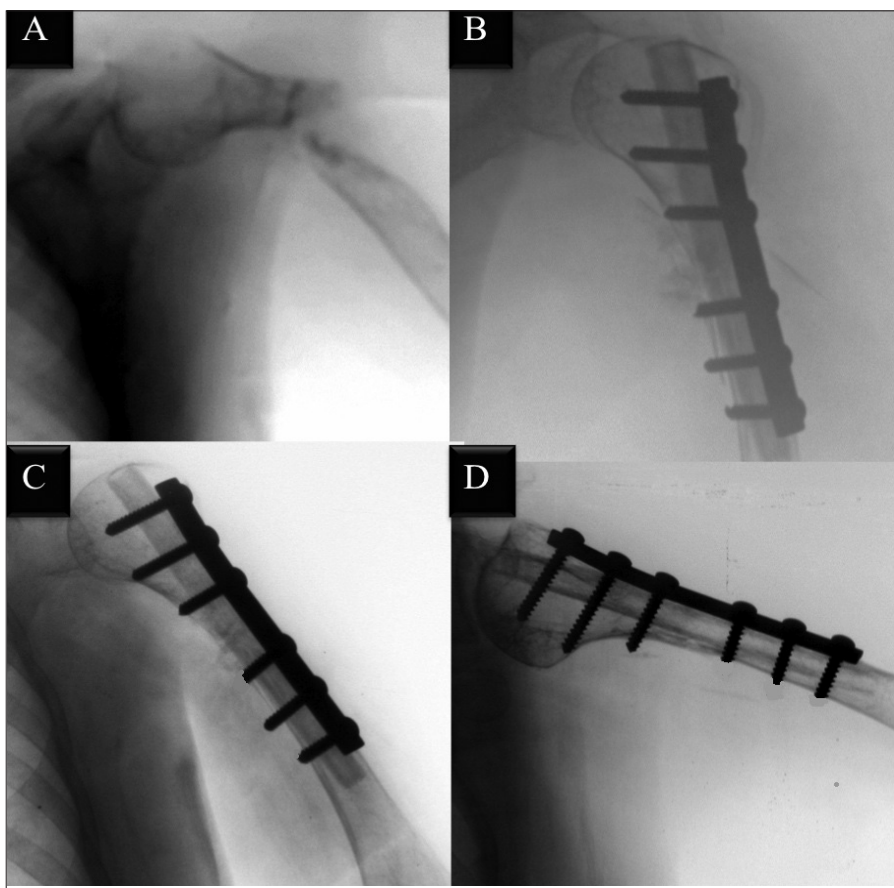

Figure 2. Preoperative AP X-Ray showing humerus shaft atropic nonunion following fracture in a 65-year-old female (A). Post op AP X-ray (B). Solid consolidation maintained at $12 \mathrm{w}$ (C). $4 \mathrm{yr}$-follow-up, the autograft is completely incorporated (D)

non-unions (7-10). Compression plating with autogenous grafting is accepted as the gold standard method so has yielded satisfactory results, with 92 to $100 \%$ healing rates $(1-5,11,21)$. In this technique, engaging at least 6 cortices on either side of the non-union with screws is advised (11). On the other hand, such a large-scale dissection is sometimes morbid for the patient $(11,18)$. Recently, locking compression plates which allow the interlocking of the plate and the screw make it bio-mechanically more stable against forces acting on the fracture surfaces, but their use is limited due to problems with cost and availability $(18,19)$.

Interlocking nails or external fixators are not viable options in these obese and elderly patients as the adjacent joints may already be stiff at the time of presentation $(5,9,10)$.

The use of plate fixation without bone grafting is limited by the bone quality and therefore the ability to obtain good screw fixation is low. Iliac crest cancellous bone graft has no mechanical strength to withstand stresses but fibula strut graft has (20). The fibula acts as an internal splint to the fracture site, aiding stability of osteosynthesis and pullout strength of the screws in this technique. The ease of fibular harvest makes its use attractive as an intramedullary bone strut for the humeral shaft. A possible disadvantage of this technique is the disruption of both the periosteal and the endosteal blood supply $(11,18-21)$.

In another more recent study, six patients were followed for an average of 13 months after receiving fibular allograft struts in addition to compression plating for the treatment of proximal humerus non-unions (15). Also Farouk et al (16). treated ten patients with the same technique and reported excellent results. They all showed successful union at their last followup. Although these results are promising, the sample size is small and the study period is short. We also have experience with four overweight patients with non-union treated by the same surgical technique and had a similar rate of union.
The results in our limited number series with almost no complications favour this easy and reliable option.

The surgical treatment of humerus diaphyseal non-unions in elderly and obese patients is not only difficult but also costly. Moreover, time consuming surgical interventions brings life-threatening risks in particular in those patient populations. Thus, we consider this method to be an applicable treatment alternative where humerus diaphyseal union is obtained.

Conflict of interest: No conflict of interest was declared by the authors.

\section{REFERENCES}

1. Ring $D$, Perey $B H$, Jupiter JB. The functional outcome of operative treatment of ununited fractures of the humeral diaphysis in older patients. J Bone Joint Surg Am 1999; 81: 177-90.

2. Sarmiento A, Zagorski JB, Zych GA, Latta LL, Capps CA. Functional bracing for the treatment of fractures of the humeral diaphysis. J Bone Joint Surg Am 2000; 82: 478-86.

3. Jupiter JB, Von Deck M. Ununited humeral diaphyses. J Shoulder Elbow Surg 1998; 7: 644-53. [CrossRef]

4. Pugh DMW, McKee MD. Advances in the management of humeral non-union. J Am Acad Orthop Surg 2003; 1: 48-59.

5. Weber BG. Minimax fracture fixation. AO Masters Series. Stuttgart: Thieme Medical Publishers, 2004.

6. Ring D, Kloen P, Kadzielski J, Helfet D, Jupiter JB. Locking compression plates for osteoporotic non-unions of the diaphyseal humerus. Clin Orthop 2004; 425: 50-4. [CrossRef]

7. Van Houwelingen AP, McKee MD. Treatment of osteopenic humeral shaft non-union with compression plating, humeral cortical allograft struts, and bone grafting. J Orthop Trauma 2005; 9: 36-42. [CrossRef] Ilyas I, Younge DA. Locked intramedullary nailing for diffcult non-unions of the humeral diaphysis. Int Orthop 2003; 27: 278-81. [CrossRef]

9. Martinez AA, Cuenca J, Herrera A. Treatment of humeral shaft nonunions: nailing versus plating. Arch Orthop Trauma Surg 2004; 124: $92-5$. [CrossRef]

10. Kocaoglu M, Eralp L, Tomak Y. Treatment of humeral shaft non-unions by the llizarov method. Int Orthop 2001; 25: 396-400. [CrossRef]

11. Marti RK, Verheyen CC, Besselaar PP. Humeral shaft non-union: evaluation of uniform surgical repair in fifty-one patients. J Orthop Trauma 2002; 16: 108-15. [CrossRef]

12. Gonzalez del Pino J, Bartolome del Valle E, Lopez Grana G, Ferreira Villanova J. Free vascularized fibula grafts have a high union rate in atrophic non-unions. Clin Orthop Relat Res 2004; 419: 38-45. [CrossRef]

13. Adani $R$, Delcroix L, Innocenti M, Tarallo L, Baccarani A. Free fibula flap for humerus segmental reconstruction: report on 13 cases. Chir Organi Mov 2008; 91: 21-6. [CrossRef]

14. Hornicek FJ, Zych GA, Hutson JJ, Malinin TI. Salvage of humeral non-unions with onlay bone plate allograft augmentation. Clin Orthop 2001; 386: 203-9. [CrossRef]

15. Vidyadhara S, Vamsi K, Rao SK, Gnanadoss JJ, Pandian S. Use of intramedullary fibular strut graft: a novel adjunct to plating in the treatment of osteoporotic humeral shaft non-union. International Orthopaedics (SICOT). [DOI 10.1007/s00264-008-0596-x]. June 19, 2008. Available from: www. Springerlink. com, Springer, Berlin. [CrossRef]

16. Farouk O, El-Sherif E, Mostafa K, Khalil A. Intramedullary fibular graft and quadricortical plate fixation in atrophic non-union of the osteoporotic humerus. Injury Extra 2008; 39: 152-4. [CrossRef]

17. Jupiter JB, Ring D, Rosen $H$. The complications and difficulties of management of non-union in the severely obese. J Orthop Trauma 1995; 9: 363-70. [CrossRef]

18. Gregory PR Jr. Fractures of the shaft of the humerus. In: Bucholz RW, Heckman J, eds. Rockwood and Green's Fractures in Adults, 5th edition. Philadelphia, PA: Lippincott Williams \&Wilkins; 2001; 973-96.

19. Ring D, Jupiter J. Ununited Diaphyseal Fractures of the Humerus: Techniques for Fixation of Osteoporotic Bone. Tech Hand and Up Extrem Surg 2003; 7: 2-6. [CrossRef]

20. Ahrens PH, Nicoletti S, Houghton-Clemmey RSA. Non-union of the Surgical Neck of the Humerus: Treatment With Fibular Graft and Locking Plate Fixation. Tech Should Surg 2010; 11: 15-8. [CrossRef]

21. Hierholzer C, Sama D, Toro JB, Peterson M, Helfet DL. Plate fixation of ununited humeral shaft fractures: effect of type of bone graft on healing. J Bone Joint Surg. 2006; 88A: 1442-7. [CrossRef] 